\title{
Activation and Desensitization of AMPA/Kainate Receptors by Novel Derivatives of Willardiine
}

\author{
Doris K. Patneau, ${ }^{1}$ Mark L. Mayer, ${ }^{1}$ David E. Jane, ${ }^{2}$ and Jeffrey C. Watkins ${ }^{2}$ \\ 'Section of Neurophysiology and Biophysics, Laboratory of Developmental Neurobiology, NICHD, National Institutes of \\ Health, Bethesda, Maryland, 20892 and ${ }^{2}$ Department of Pharmacology, School of Medical Sciences, University of Bristol, \\ Bristol BS8 1TD, United Kingdom.
}

\begin{abstract}
Willardiine [(S)-1-(2-amino-2-carboxyethyl)pyrimidine-2,4dione] is a naturally occurring heterocyclic excitatory amino acid present in the seeds of Acacia and Mimosa. A series of 5-substituted willardiines were synthesized in single enantiomeric forms and tested for activity at AMPA/kainate receptors, using whole-cell recording from mouse embryonic hippocampal neurons. The (S)- but not $(R)$-isomers of willardiine and 5-bromowillardiine were potent agonists, producing rapidly but incompletely desensitizing responses. At equilibrium, (S)-5-fluorowillardiine $\left(\mathrm{EC}_{50}, 1.5 \mu \mathrm{M}\right)$ was seven times more potent than $(R, S)$-AMPA $\left(E_{50}, 11 \mu \mathrm{M}\right)$ and 30 times more potent than willardiine $\left(\mathrm{EC}_{50}, 45 \mu \mathrm{M}\right)$; the potency sequence was fluoro $>$ nitro $>$ chloro $\approx$ bromo $>$ iodo $>$ willardiine. Willardiines produce strikingly different degrees of desensitization: at saturating doses the equilibrium response to the weakly desensitizing agonist (S)-5-iodowillardiine was similar in amplitude to the response to kainate and 10 times larger than the response to the strongly desensitizing agonist $(S)$-willardiine. The desensitization sequence was fluoro $>$ willardiine $>$ nitro $\approx$ chloro $>$ bromo $>$ iodo $>$ kainate. Cross-desensitization experiments confirm that willardiines bind to the same receptors activated by kainate and AMPA, and show that both the rapidly desensitizing and equilibrium responses to willardiines are mediated by the same receptor: (S)-5-iodowillardiine blocked activation of the rapidly desensitizing response evoked by (S)-willardiine and (S)-5-fluorowillardiine, while the latter agonists blocked the equilibrium response to (S)-5-iodowillardiine. A slowly decaying inward tail current was recorded after a brief application of (S)-5-fluorowillardiine but not (S)willardiine, consistent with a model in which willardiines bind with different affinity to desensitized receptors, such that following removal of agonist, receptors trapped in the desensitized state can return to the open state before dissociation of agonist terminates receptor activation. Willardiines are the first compounds characterized in which simple changes in molecular structure are associated with marked differences in the ability of agonists to produce desensitization of AMPA/kainate receptors.
\end{abstract}

\footnotetext{
Received July 23, 1991; revised Sept. 24, 1991; accepted Sept. 26, 1991.

We thank Christine Winters for preparation of cell cultures, Dr. P. M. Udvarhelyi for chiral HPLC analyses, Dr. J. Clements for computer programs, and Drs. M. Benveniste and L. Vyklicky Jr. for comments on the manuscript. D.K.P. is an NIH IRTA fellow.

Correspondence should be addressed to Dr. M. L. Mayer, Building 36, Room 2A21, National Institutes of Health, Bethesda, MD 20892.

Copyright (C) 1992 Society for Neuroscience $0270-6474 / 92 / 120595-12 \$ 05.00 / 0$
}

Recent advances in molecular biology suggest that the heterocyclic amino acids AMPA and kainate activate a common family of glutamate receptors: homomeric receptors generated by in vitro expression of cDNAs coding for single glutamate receptor subunits are activated by both agonists (Boulter et al., 1990; Keinånen et al., 1990; Nakanishi et al., 1990; Sommer et al., 1990), and the responses generated by such receptors share many physiological characteristics with those reported for native nonNMDA glutamate receptors in embryonic and adult CNS neurons (Kiskin et al., 1986, 1990; Mayer and Vyklicky, 1989; O'Dell and Christensen, 1989; Tang et al., 1989; Trussell and Fischbach, 1989; Patneau and Mayer, 1990, 1991). In particular, responses to AMPA are strongly desensitizing and at equilibrium competitively antagonize the large-amplitude, nondesensitizing response evoked by kainate (O'Brien and Fischbach, 1986; Perouansky and Grantyn, 1989; Keinånen et al., 1990; Lambolez et al., 1991; Patneau and Mayer, 1991). The reason for the markedly different physiological responses of CNS neurons to AMPA and kainate is unknown but may reflect differences in the relative affinity of AMPA and kainate for the active and desensitized states of the receptor (Patneau and Mayer, 1991). As part of a program to develop novel agonists that may be useful for the future characterization of glutamate receptor subtypes on neurons in the intact CNS, we describe here responses evoked by a series of 5 -substituted willardiines at AMPA kainate receptors in embryonic hippocampal neurons.

Evans and Watkins were the first to examine the physiological action of willardiine, 1-(2-amino-2-carboxyethyl)pyrimidine-2,4dione, the $(S)$-form of which occurs naturally in the seeds of several species of Acacia and Mimosa (Gmelin, 1961). In these experiments synthetic $(R, S)$-willardiine was found to be a potent agonist at non-NMDA receptors present on rat spinal motoneurons (Evans et al., 1980). Subsequent studies, in which isolated preparations of rat dorsal root fibers were found to respond strongly to kainate but only weakly to AMPA, provided physiological evidence suggestive of separate kainate and AMPA receptors (Agrawal and Evans, 1986), and in this preparation $(R, S)$-5-bromowillardiine was a potent excitant, while $(R, S)$ willardiine was inactive. Thus, 5-bromowillardiine was suggested to be a selective kainate receptor agonist, and willardiine, a selective AMPA receptor agonist. Recent experiments on sensory neurons, which revealed rapid and complete desensitization of responses to AMPA, glutamate, and quisqualate (Huettner, 1990), raised the possibility that the weak response of sensory neuron axons to bath application of AMPA and quisqualate, and the lack of any response to willardiine (Agrawal and Evans, 1986), could instead result from desensitization. If this were 
true, 5-bromowillardiine would be expected to be a kainate-like agonist and produce only weak desensitization when applied to CNS neurons, while willardiine would be expected to produce strongly desensitizing responses similar to those evoked by AMPA. Experiments on Xenopus oocytes injected with rat or chick brain mRNA revealed small responses to willardiine, large responses to 5-bromowillardiine, and cross-desensitization of responses to kainate by willardiine but not 5-bromowillardiine and thus appeared to confirm this prediction (Sugiyama et al., 1990; see also Bowie and Smart, 1990). In addition, recent experiments on rat hippocampal neurons show strong desensitization evoked by $(R, S)$-willardiine, but less than $10 \%$ desensitization evoked by $(R, S)$-5-bromowillardiine (Zorumski et al., 1991). This is of considerable interest because, with the exception of kainate and domoate, all other non-NMDA receptor agonists examined to date evoke strongly desensitizing responses at CNS AMPA/kainate receptors (Kiskin et al., 1986, 1990; Patneau and Mayer, 1990, 1991). To explore this issue further, we examined the physiological activity of willardiine and a series of novel 5-substituted derivatives applied by concentration jump to hippocampal neurons under voltage clamp.

Preliminary results have been reported previously (Patneau et al., 1991).

\section{Materials and Methods}

Cell culture. Experiments were performed on primary dissociated cultures of mouse embryonic hippocampus. Neuronal cultures were prepared by dissociating the hippocampi of $16-17$-d-old C57Bl/6 mouse embryos and plating the resulting cell suspension onto confluent hippocampal glial cell feeder layer cultures. The mothers were killed by cervical dislocation prior to removal of the fetuses. The growth medium was minimum essential medium (MEM) with $5 \%$ horse serum, and a nutrient supplement containing transferrin, insulin, selenium, corticosterone, triiodothyronine, progesterone, and putrescine (Guthrie et al., 1987); no antibiotics were used. Further details are given in Mayer et al. (1989).

Recording and perfusion techniques. Experiments were performed at room temperature $\left(25-27^{\circ} \mathrm{C}\right) 6-12 \mathrm{~d}$ after cultures were plated. Wholecell patch-clamp recording was performed using an Axon Instruments Axoclamp 2 discontinuous voltage-clamp amplifier set at a gain of 2$4 \mathrm{nA} / \mathrm{mV}$, with a switching frequency of approximately $10 \mathrm{kHz}$. The series resistance was typically 7-9 $\mathrm{m} \Omega$. The recording chamber was perfused at $0.5-1.0 \mathrm{ml} / \mathrm{min}$ with extracellular solution. The fast perfusion system has been described previously (Mayer and Vyklicky, 1989) and consisted of an array of nine glass tubes (each $356 \mu \mathrm{m}$ i.d., $406 \mu \mathrm{m}$ o.d.) positioned approximately $100 \mu \mathrm{m}$ from the cell soma. Rapid solution changes were achieved using solenoid valves to switch the flow between adjacent barrels immediately after a stepper motor moved the appropriate barrel into position above the neuron. We have previously shown that the time constant for solution exchange around the cell soma and surrounding dendrites was $10 \mathrm{msec}$ or less (Vyklicky et al., 1990).

Experimental solutions. The extracellular solution contained (in $\mathrm{mM}$ ) $160 \mathrm{NaCl}, 2.5 \mathrm{KCl}, 2 \mathrm{CaCl}_{2}, 1 \mathrm{MgCl}_{2}, 10 \mathrm{HEPES}, 10$ glucose, and 0.01 $\mathrm{mg} / \mathrm{ml}$ phenol red; $\mathrm{pH}$ was adjusted to 7.3 with $\mathrm{NaOH}$. Tetrodotoxin (400 nM) was added to block action potentials and synaptic activity, and bicuculline methochloride $(5 \mu \mathrm{M})$ was added to block spontaneous inhibitory postsynaptic potentials. Although responses to $(R, S)$-willardiine and $(R, S)$-5-bromowillardiine are not sensitive to block by NMDA rccptor antagonists, suggesting that they are selective agonists acting at non-NMDA receptors (Davies et al., 1982), glycine was not added to the extracellular solution and the magnesium concentration was maintained at $1 \mathrm{~mm}$ during agonist application to prevent activation of NMDA receptors. The intracellular solution for whole-cell recording contained (in mM) $125 \mathrm{CsMeSO}_{3}, 15 \mathrm{CsCl}, 10 \mathrm{HEPES}, 5$ BAPTA, 0.5 $\mathrm{CaCl}_{2}, 3 \mathrm{MgCl}_{2}$, and $2 \mathrm{Na}_{2}-\mathrm{ATP}$; $\mathrm{pH}$ was adjusted to 7.2 with $\mathrm{CsOH}$ and osmolarity to $305 \mathrm{mOsm}$ with sucrose if necessary.

Willardiine and its derivatives were prepared by selective enantiomeric synthesis from suitably substituted uracil precursors and purified by resin column chromatography. Enantiomeric purity was determined from the relative areas of peaks obtained in chiral HPLC chromatography (Crownpak, Daicel Chemical Industries, Tokyo), using the racemates if available, together with the separate isomers for identification of enantiomeric positions in the elution sequence (D. E. Jane and J. C. Watkins, unpublished observations). The enantiomeric purity of the various $(S)$-isomers was between $97 \%$ and $99 \%$; the $(R)$-isomers of 5 -bromowillardiine and willardiine showed enantiomeric purity of approximately $99 \%$ and $>99 \%$, respectively. Racemic willardiine and 5 -bromowillardiine was obtained from Tocris Neuramin.

Results are presented as mean $\pm \mathrm{SD}$, unless stated differently.

\section{Results \\ Enantiomeric selectivity of ( $\mathrm{R})$ - and (S)-willardiine and 5-bromowillardiine}

Following preliminary experiments performed with racemic mixtures of willardiine and 5-bromowillardiinc, which revealed rapidly but incompletely desensitizing responses to both agonists (L. Vyklicky Jr. and M. L. Mayer, unpublished observations), we tested the activity of the corresponding $(S)$ - and $(R)$ isomers applied at concentrations that produced near-maximal equilibrium responses for the racemic mixtures. These experiments were performed on eight hippocampal neurons, each tested with the $(S)$ - and $(R)$-enantiomers of both willardiine and 5 -bromowillardiine, and revealed the following differences in behavior. First, the $(S)$-isomers of both ligands were strong agonists, while the $(R)$-isomers were either essentially inactive (willardiine) or of much lower potency (5-bromowillardiine). Second, both the peak and equilibrium responses to $200 \mu \mathrm{M}(S)$ 5-bromowillardiine were much larger than those to $1 \mathrm{mM}(S)$ willardiine (Fig. 1). Third, although the $(S)$-isomers of both agonists produced strongly desensitizing responses, willardiine produced more desensitization $(90 \pm 5 \%$; defined as [ 1 - (steady state/peak response) $\times 100)$ than 5-bromowillardiine $(75 \pm$ $2 \%$ ). At $200 \mu \mathrm{M},(R)-5$-bromowillardiine did not produce any desensitization (Fig. 1); however, at higher concentrations rapidly desensitizing responses were observed (not shown).

The following observations suggest that the $(R)$-isomers of both willardiine and 5-bromowillardiine are completely inactive and that the small responses illustrated in Figure 1 can be entirely accounted for by contamination with the active, $(S)$-isomers. Analysis of equilibrium dose-response curves for the $(S)$ isomers (Fig. 2) indicates that the residual response to $1 \mathrm{~mm}$ $(R)$-willardiine, which was only barely detectable (Fig. 1), could result from $0.54 \%$ contamination with the active, $(S)$-isomer. This is consistent with the value of $0.2 \%$ contamination determined by chiral chromatography. Equilibrium responses evoked by $200 \mu \mathbf{M}(R)$-5-bromowillardiine were much larger than those for $1 \mathrm{~mm}(R)$-willardiinc, and indecd werc comparable in sizc to responses evoked by a saturating dose of the active, $(S)$ isomer of willardiine (Fig. 1). However, contamination with only $1.14 \%(S)$-5-bromowillardiine would entirely account for the agonist response to $200 \mu \mathrm{M}(R)$-5-bromowillardiine. Again, this value is comparable with the estimate from chiral chromatography of $1 \%$ contamination with the $(S)$-isomer. Experiments with $(R, S)$-willardiine and $(R, S)$-5-bromowillardiine did not suggest any antagonist action of the $(R)$-isomers, the $\mathrm{EC}_{50}$ values obtained with the racemic mixtures $(16.9 \pm 7.3 \mu \mathrm{M}$ for 5-bromowillardiine and $99.9 \pm 39 \mu \mathrm{M}$ for willardiine) being approximately twice those obtained with the $(S)$-isomers (see Table 1).

The results illustrated in Figure 1 suggest marked differences in the potency, efficacy, and degree of desensitization for responses evoked by willardiine and its 5 -brominated derivative. 
A
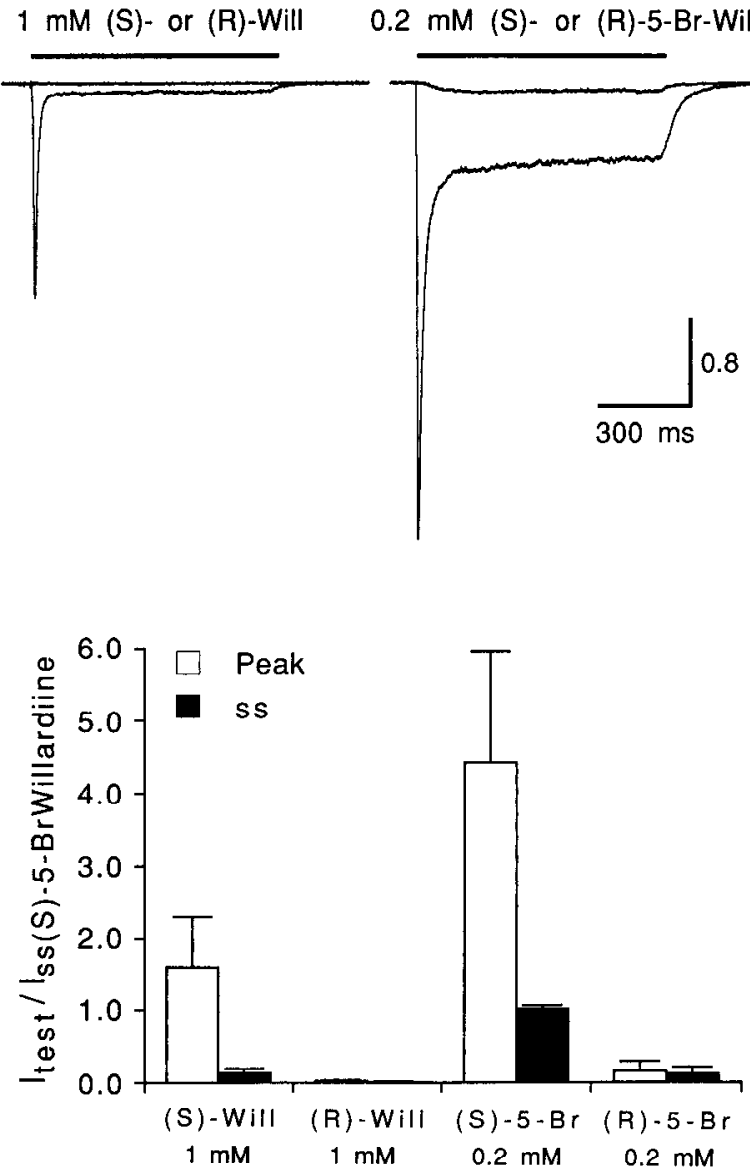

Figure 1. Enantiomeric selectivity of $(R)$ - and $(S)$-willardiine and $(R)$ and $(S)$-5-bromowillardiine. $A$, Responses to $1 \mathrm{~mm}(S)$ - and $(R)$-willardiine and $200 \mu \mathrm{M}(S)$ - and $(R)$-5-bromowillardiine were recorded from a single neuron [upper traces, $(R)$-forms; lower traces, $(S)$-forms]. $B a r s$ above the traces mark time of agonist application. At these concentrations the $(S)$-enantiomers produce maximal steady-state responses. Note that $(S)$-5-bromowillardiine produces both a larger peak and a larger steady-state response than $(S)$-willardiine. The small response to $200 \mu \mathrm{M}(R)$-5-bromowillardiine is consistent with $1 \%$ contamination with the (S)-enantiomer. $B$, Mean data from eight experiments as illustrated in $A$ (error bars show $1 \mathrm{SD}$ ). Values are normalized relative to the steady-state (ss) response for $200 \mu \mathrm{M}(S)$-5-bromowillardiine.

We examined these issues further by studying the kinetics of responses to the $(S)$-isomers of willardiine and five derivatives, with $\mathrm{F}, \mathrm{Cl}, \mathrm{Br}$, I, or $\mathrm{NO}_{2}$ substituted at the 5-position of the uracil ring.
A

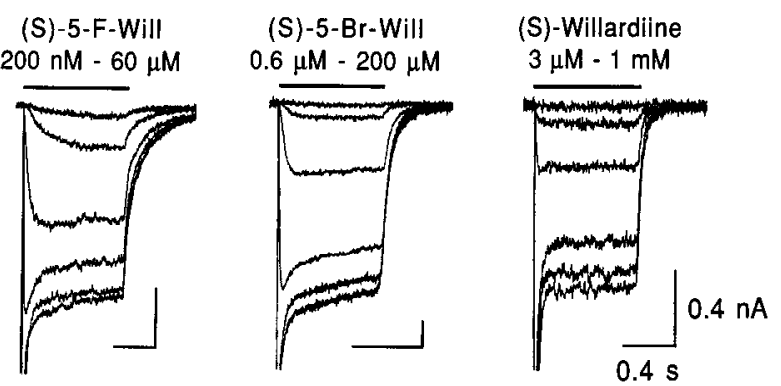

B

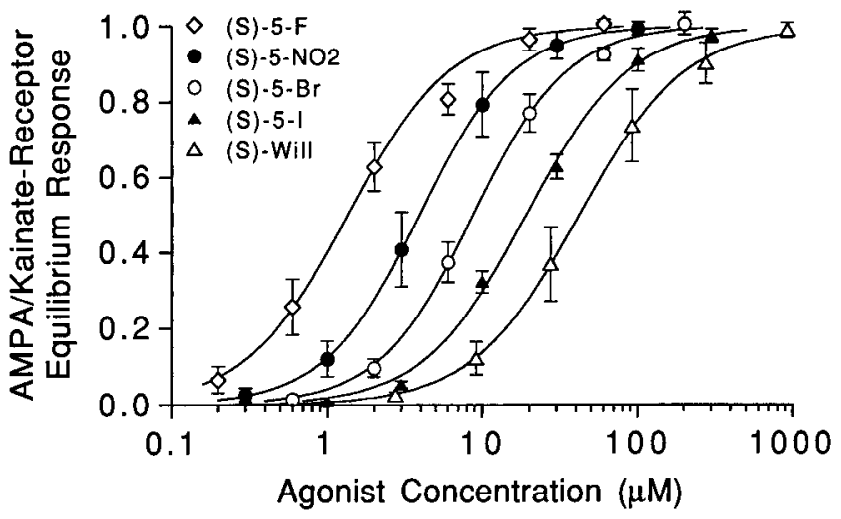

Figure 2. Equilibrium dose-response analysis for AMPA/kainate receptor activation by willardiines. $A$, Examples of responses to $(S)-5$ fluorowillardiine, $(S)$-5-bromowillardiine, and $(S)$-willardiine applied over the concentration range indicated above each set of traces. Bars above the traces mark time of agonist application. Each agonist was tested in a different cell, and traces are plotted at different gains to facilitate comparison (see calibration). $B$, Equilibrium dose-response data from four to seven cells (8-12 observations) for the three agonists illustrated in $A$, plus $(S)$-5-nitrowillardiine and $(S)$-5-iodowillardiine, were fit with the logistic equation $I-I_{\max } \times\left\{1 / 1+\left(\mathrm{EC}_{50} /[\text { dose }]\right)^{n}\right\}$. For illustrative purposes only, dose-response data from individual neurons were normalized relative to $I_{\max }$, the results pooled, and the means fit to the logistic equation; data points show mean values $\pm \mathrm{SD}$.

\section{Structure-activity analysis for potency and efficacy of 5-substituted willardiine derivatives}

Willardiine and its derivatives evoked responses typical of those produced by AMPA, quisqualate, and glutamate, but not kainate or domoate. Sustained responses, which could be maintained for several minutes, were evoked by low concentrations of ag-

Table 1. Steady-state $\mathrm{EC}_{50}$ values and equilibrium efficacy for willardiines

\begin{tabular}{lllll} 
Compound & $\mathrm{EC}_{\text {s0 }}(\mu \mathrm{M})$ & Hill coefficient & $I_{\text {sS }} / I_{\text {Kai }}$ & $\begin{array}{l}\text { \% Desensiti- } \\
\text { zation }\end{array}$ \\
\hline$(S)$-willardiine & $44.8 \pm 15.0$ & $1.32 \pm 0.12$ & $0.09 \pm 0.04$ & $90.9 \pm 3.0$ \\
$(S)$-F-willardiine & $1.47 \pm 0.39$ & $1.22 \pm 0.11$ & $0.15 \pm 0.06$ & $92.5 \pm 3.1$ \\
$(S)$-NO -willardiine & $4.10 \pm 1.45$ & $1.49 \pm 0.14$ & $0.24 \pm 0.05$ & $86.4 \pm 3.1$ \\
$(S)$-Cl-willardiine & $7.28 \pm 2.06$ & $1.32 \pm 0.15$ & $0.27 \pm 0.07$ & $86.5 \pm 3.8$ \\
$(S)$-Br-willardiine & $8.82 \pm 1.29$ & $1.46 \pm 0.11$ & $0.58 \pm 0.08$ & $74.3 \pm 7.6$ \\
$(S)$-I-willardiine & $19.2 \pm 1.92$ & $1.33 \pm 0.07$ & $0.89 \pm 0.08$ & $63.6 \pm 9.6$
\end{tabular}

$\mathrm{EC}_{50}$ values and Hill cocfficients were derived from analysis of 8-12 dose-response curves per agonist (recorded from four to seven cells) using the logistic equation; values are mean \pm SD. Steady-state currents $\left(I_{\text {ss }}\right)$ were evoked by willardiines applied at $100 \times$ the equilibrium $\mathrm{EC}_{50}$ value, and were normalized with respect to the response evoked by $6 \mathrm{mM}$ kainate $\left(I_{\mathrm{Kat}} ;\right.$ mean \pm SD of observations from six to eight cells per agonist). The percentage desensitization (mean $\pm \mathrm{SD} ; n=5-8$ cells per agonist) was computed from the response to saturating doses of agonist (300 $\times$ equilibrium $\left.\mathrm{EC}_{50}\right)$ as $[1-($ steady-state/peak response) $] \times 100$. 
A
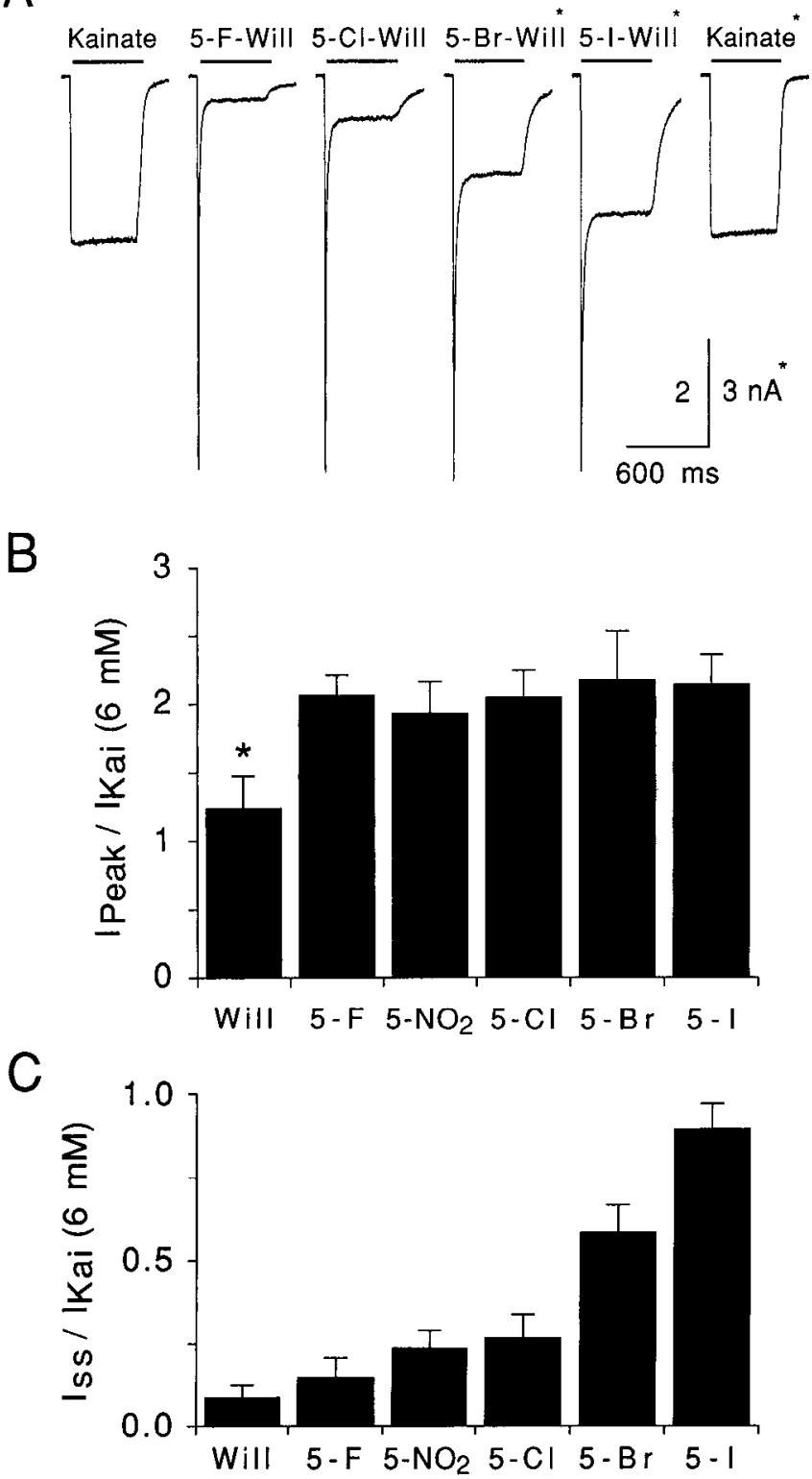

Figure 3. Comparison of agonist efficacy for peak and equilibrium responses at AMPA/kainate receptors. A, Rapidly desensitizing responses produced by saturating doses of 5 -substituted willardiines applied during the period marked by bars above the traces. Responses are from two cells, and traces are scaled relative to the amplitude of the response to $6 \mathrm{~mm}$ kainate recorded in the same cell (traces from the same cell are indicated by the presence or absence of an asterisk). Note that 5-fluoro-, 5-chloro-, 5-bromo-, and 5-iodowillardiine produce similar amplitude peak responses relative to kainate but differ in efficacy for equilibrium responses. The onset of desensitization in response to willardiines was rapid and best fit by the sum of two exponentials; for the traces illustrated the fast and slow time constants $\left(\tau_{f}\right.$ and $\left.\tau_{s}\right)$ were fluoro: $\tau_{f}, 11.1 \mathrm{msec}(82 \%), \tau_{s}, 47 \mathrm{msec}(18 \%)$; chloro: $\tau_{f}, 12.4 \mathrm{msec}$ $(85 \%), \tau_{s}, 69 \mathrm{msec}(15 \%)$; bromo: $\tau_{,}, 9.8 \mathrm{msec}(73 \%), \tau_{s}, 34 \mathrm{msec}(27 \%)$; and iodo: $\tau_{f}, 10.9 \mathrm{msec}(68 \%), \tau_{s}, 29 \mathrm{msec}(32 \%) . B$. Comparison of the amplitude of peak responses to saturating doses of willardiines (agonists were applied at approximately $300 \times$ equilibrium $\mathrm{EC}_{50}$ values) normalized relative to the response to $6 \mathrm{~mm}$ kainate (mean \pm SD for four to seven cells per agonist). For willardiine, ${ }^{*}$ indicates a significant difference $(p<0.01$, ANOVA). $C$, Comparison of equilibrium responses produced by willardiines (agonists were applied at $100 \times$ equilibrium $\mathrm{EC}_{50}$ values, producing maximal steady-state responses) normalized relative to the response produced by $6 \mathrm{~mm}$ kainate. Three willardiines and kainate were tested in each neuron. Data shown are mean \pm SD for six to eight cells per agonist. onist and produced only a small increase in membrane current noise. However, at agonist concentrations above the $\mathrm{EC}_{50}$ for equilibrium responses, a much larger amplitude, rapidly desensitizing response developed (Fig. 2). Because the dose-response relationship for rapidly desensitizing responses at AMPA/kainate receptors is not adequately resolved in whole-cell recording experiments (Patneau and Mayer, 1990), only measurements at equilibrium were analyzed. $\mathrm{EC}_{50}$ values for equilibrium responses to willardiine and its derivatives spanned a 30 -fold range of potency, with $(S)$-5-fluorowillardiine the most potent agonist examined $\left(\mathrm{EC}_{\mathrm{s} 0}, 1.5 \pm 0.4 \mu \mathrm{M}\right)$ and willardiine the least potent $\left(\mathrm{EC}_{50}, 44.8 \pm 15 \mu \mathrm{M}\right)$. The potency sequence was fluoro $>$ nitro $>$ chloro $\approx$ bromo $>$ iodo $>$ willardiine (Table 1 ). It should be noted that equilibrium $\mathrm{EC}_{50}$ values are unlikely to reflect a true dissociation constant for binding of willardiines to AMPA/kainate receptors, but rather a weighted average of their different affinities for the active and desensitized states of the receptor.

In previous experiments performed with AMPA and quisqualate, we found that the amplitude of the rapidly desensitizing (peak) response at non-NMDA receptors was near maximal at agonist doses approximately 300 times the equilibrium $\mathrm{EC}_{50}$ (Patneau and Mayer, 1991). A similar strategy was used to examine the action of willardiine and its derivatives for possible differences in efficacy. In order to control for differences in receptor density between neurons, measurements of the peak current evoked by willardiine and its derivatives were normalized to the response evoked by a saturating dose of kainate $(6 \mathrm{~mm}$; see Patneau and Mayer, 1991). Typically, responses to kainate and three to five willardiine derivatives were recorded from the same neuron. Our results revealed no significant difference in efficacy for the 5-substituted willardiine derivatives examined. For example, the peak amplitude of responses to 5-fluorowillardiine, which produced strong desensitization, was similar to the peak amplitude of responses evoked by 5 -iodowillardiine, which produced much weaker desensitization (Fig. 3). However, as suggested by the preliminary experiments illustrated in Figure 1 , willardiine itself was less efficacious than the other agonists tested and on average produced peak currents only $60 \%$ as large as those evoked by its 5 -substituted derivatives (Fig. $3 B$ ); this difference was significant (ANOVA, $F=8.3(5,25), p<0.01$; Tukey-B, $p<0.01$ ).

In contrast to results obtained when peak responses were measured, analysis of equilibrium responses revealed marked differences in amplitude for all of the 5-substituted willardiine derivatives examined (Fig. 3C). Responses evoked by agonist concentrations that produced a maximal equilibrium response (100 times the equilibrium $\mathrm{EC}_{50}$ ) varied in amplitude by greater than 10-fold, with willardiine the least efficacious agonist (8.6 $\pm 3.8 \%$ of the response to $6 \mathrm{~mm}$ kainate) and 5-iodowillardiine the most efficacious agonist $(89.4 \pm 7.6 \%$ of the response to 6 mM kainate). The equilibrium efficacy sequence was iodo $>$ bromo $>$ chloro $\approx$ nitro $>$ fluoro $>$ willardiine (Fig. 3 ).

\section{Agonist sensitive desensitization evoked by 5-substituted willardiines}

Kainate and domoate produce very weakly densensitizing responses in hippocampal neurons, while all other non-NMDA receptor agonists examined previously [quisqualate, AMPA, (S)glutamate, $S$-sulfo-(S)-cysteine, $(S)$-serine- $O$-sulfate, $(S)$-homocysteate, $(R)$-homocysteate, $(S)$-homocysteinesulfinate, $(S)$ cysteate, and $(S)$-cysteinesulfinate] produce rapidly and strongly 
desensitizing responses and show only small differences in the relative amplitude of responses at equilibrium (Kiskin et al., 1986, 1990; Mayer and Vyklicky, 1989; Tang et al., 1989; Patneau and Mayer, 1990, 1991). The 5-substituted willardiines examined in the present study behave differently from other AMPA/kainate receptor agonists and show marked differences in the amplitude of equilibrium responses due to variation in the amount of desensitization (Fig. 3A). Desensitization, calculated as $(1-$ [steady state/peak response] $) \times 100$, decreases according to the following sequence: iodo $<$ bromo $<$ nitro $\approx$ chloro $<$ willardiine $<$ fluoro, as shown by a plot of the ratio steady state/peak response (Fig. $4 A$ ). With the exception of responses to willardiine, this sequence is the inverse of the equilibrium potency sequence. The correlation between $\mathrm{EC}_{50}$ values and the amount of desensitization evoked by 5 -substituted willardiines suggests that agonists with high potency will produce more desensitization than agonists of low potency (Fig. 4B). However, willardiine, which is less potent than any of the 5 -substituted derivatives, does not follow this pattern and produces strong desensitization. Also, analysis of responses to endogenous amino acids shows that other agonists, of even lower potency, can evoke strongly desensitizing responses: $S$-sulfo-(S)-cysteine, which is of comparable equilibrium potency to (S)-willardiine, produced $98 \%$ desensitization when applied at $10 \mathrm{mM}\left(\mathrm{EC}_{50}, 59 \mu \mathrm{M}\right)$, while $(S)$-homocysteate, which is 10.6 times less potent that ( $S$ )-willardiine, also produced $98 \%$ desensitization when applied at $25 \mathrm{~mm}\left(\mathrm{EC}_{50}, 477 \mu \mathrm{M}\right)$.

\section{Cross-desensitization of responses to AMPA and kainate by 5-substituted willardiines}

Agonists acting at AMPA/kainate receptors show cross-desensitization in several experimental systems; the interpretation of such experiments is complex (Ishida and Neyton, 1985; Kiskin et al., 1986, 1990; O'Brien and Fischbach, 1986; Mayer and Vyklicky, 1989; O'Dell and Christensen, 1989; Perouansky and Grantyn, 1989; Charpentier et al., 1990; Patneau and Mayer, 1991). Preincubation with agonists such as AMPA, which evoke strongly desensitizing responses, suppresses the peak current response evoked by subsequent application of other agonists that also activate a rapidly desensitizing response, for example, quisqualate and glutamate (Kiskin et al., 1986, 1990; Patneau and Mayer, 1991). In addition, AMPA and quisqualate suppress the nondesensitizing response to kainate, but in a quasicompetitive manner (O'Brien and Fischbach, 1986; Perouansky and Grantyn, 1989; Patneau and Mayer, 1991). We have suggested that such competitive interactions occur because kainate and AMPA bind to the same agonist recognition sites, but that their affinities for the activated and desensitized states of the AMPA/ kainate receptor-channel complex are different (Patneau and Mayer, 1991). Willardiine derivatives produce a similar, complicated profile of cross-desensitization of responses to AMPA and kainate (Fig. 5).

Preincubation with $50 \mu \mathrm{M}$ 5-nitrowillardiine suppresses activation of the rapidly desensitizing response evoked by subsequent application of $1.5 \mathrm{mM}$ AMPA, but during coapplication of these agonists the larger-amplitude equilibrium response to $50 \mu \mathrm{M}$ 5-nitrowillardiine gradually decreases in amplitude in the presence of $1.5 \mathrm{~mm}$ AMPA (Fig. 5A). We suggest this occurs because AMPA produces more desensitization at equilibrium than 5-nitrowillardiine and thus suppresses the larger-amplitude response to 5-nitrowillardiine by cross-desensitization. The slow onset of this action of AMPA probably reflects both the rate of
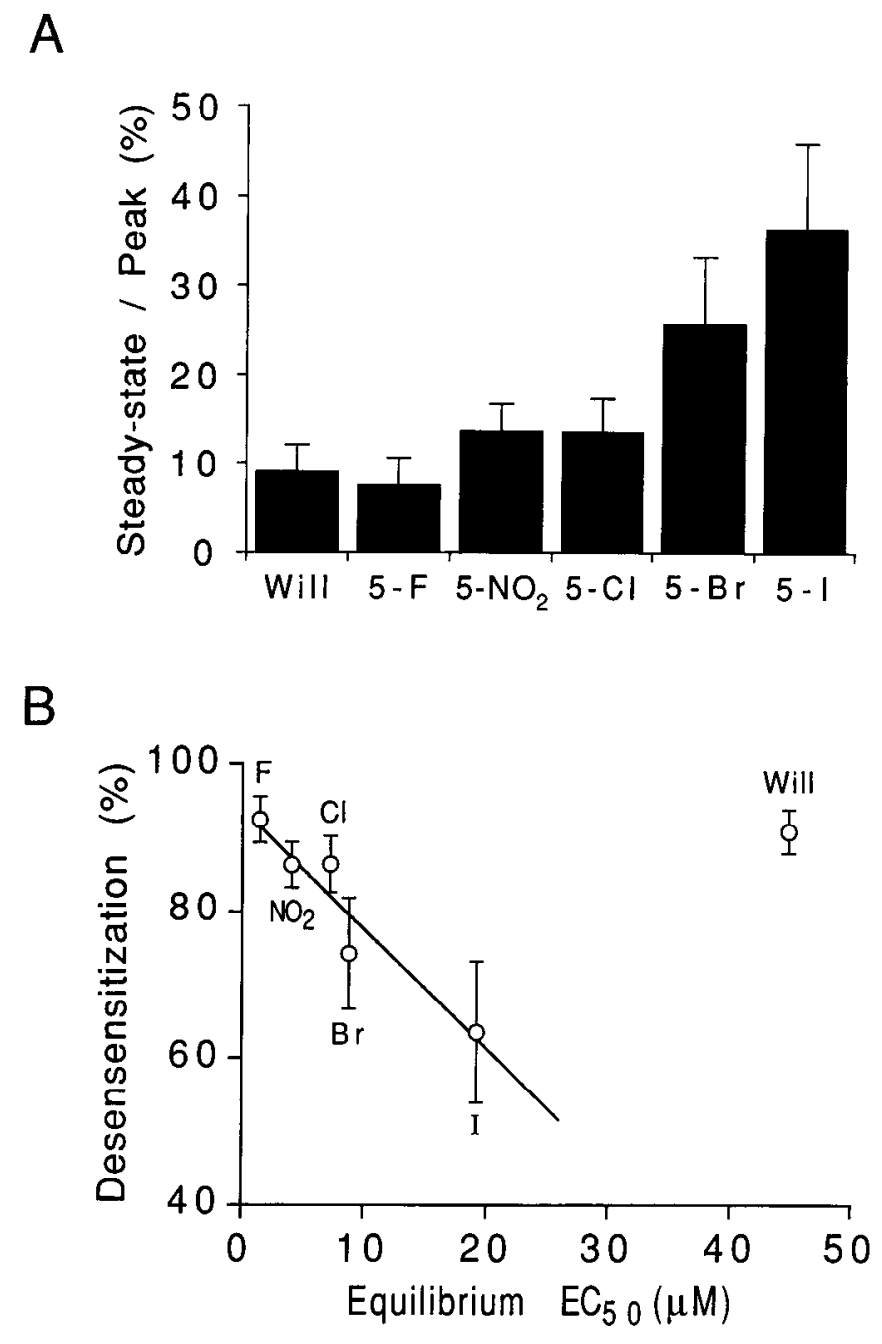

Figure 4. Desensitization at AMPA/kainate receptors is agonist dependent. $A$, Steady-state response to willardiines expressed as percentage of the peak current for responses evoked by saturating doses of agonist ( $300 \times$ equilibrium $\left.\mathrm{EC}_{50}\right) . B$, Desensitization for 5 -substituted willardiines, calculated as $[1-($ steady-state/peak response) $] \times 100$, is linearly related to agonist equilibrium potency. $\mathrm{EC}_{50}$ values are from Table 1. Data points in $A$ and $B$ show mean \pm SD for four to seven cells per agonist.

dissociation of 5-nitrowillardiine from AMPA/kainate receptors, which must occur before binding of AMPA and 5-nitrowillardiine can reach equilibrium, as well as the kinetics of transitions between 5-nitrowillardiine-bound desensitized and active states implicit in cyclic models of desensitization. The onset of cross-desensitization of responses to 5-nitrowillardiine by AMPA was well fit with the sum of two exponentials, with time constants of $96 \pm 14 \mathrm{msec}(26 \%)$ and $611 \pm 220 \mathrm{msec}(74 \%)(n=$ $6)$.

Responses to $0.6 \mathrm{~mm}$ kainate are also suppressed by prior application of $50 \mu \mathrm{M} 5$-nitrowillardiine, and responses to kainate applied in the presence of 5-nitrowillardiine show a slow inward relaxation (Fig. $5 B$ ). Based on previous experiments with AMPA and kainate, which show similar patterns of behavior (Patneau and Mayer, 1991), we suggest that this occurs because kainate and 5-nitrowillardiine compete for the same population of agonist-binding sites. Kainate, which produces a large-amplitude nondesensitizing response, cannot bind to the AMPA/kainate 
A

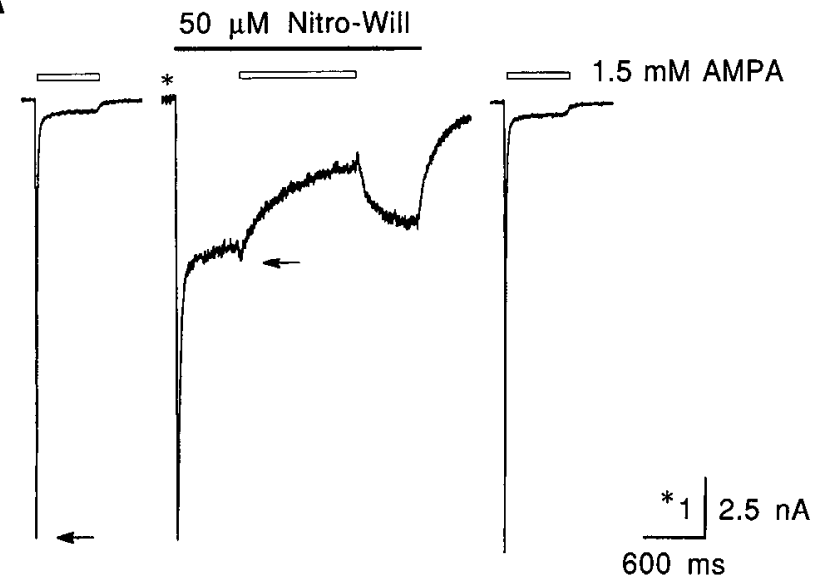

B

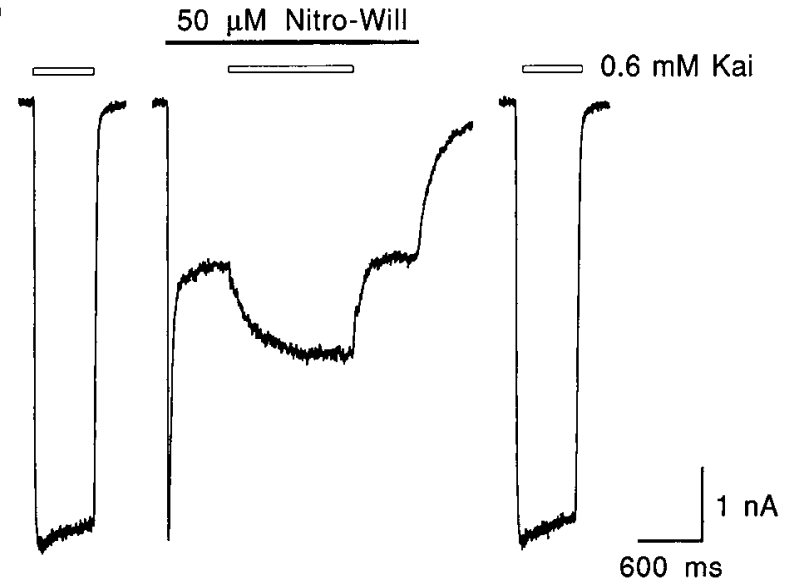

Figure 5. Cross-desensitization of responses to AMPA and kainate by 5-nitrowillardiine. Traces on the left show control responses to $1.5 \mathrm{mM}$ AMPA $(A)$ or $0.6 \mathrm{mM}$ kainate $(B)$; the middle traces show responses in the presence of $50 \mu \mathrm{M}$ 5-nitrowillardiine (which produced a small-amplitude, rapidly desensitizing response, but a near-maximal equilibrium response); traces on the right show recovery after removal of 5-nitrowillardiine. Agonist applications arc marked by bars above the traces. The results are representative of experiments on six cells. $A$, AMPA activates a rapidly desensitizing response, which is blocked in the presence of nitrowillardiine (peak responses to AMPA are indicated by arrows; different amplitude scales before and during application of 5-nitrowillardiine are indicated by ${ }^{*}$ ). Note that AMPA reversibly inhibits the steady-state response to 5-nitrowillardiine. The slow onset of crossdesensitization of the 5-nitrowillardiine response by AMPA was well fit by the sum of two exponentials, with time constants and amplitudes as follows: $\tau_{f}, 73.2 \mathrm{msec}(0.21 \mathrm{nA}) ; \tau_{s}, 514 \mathrm{msec}(1.17 \mathrm{nA}) . B$, Kainate produces a fast-activating ( $\tau=8 \mathrm{msec}$ ), weakly desensitizing response. In the presence of $50 \mu \mathrm{M} 5$-nitrowillardiine, the equilibrium response to kainate is inhibited and the kinetics of activation slowed. Activation of kainate in the presence of 5-nitrowillardiine was also well fit by the sum of two exponentials, with time constants and amplitudes as follows: $\tau_{f}, 80.0 \mathrm{msec}(0.17 \mathrm{nA}) ; \tau_{s}, 248 \mathrm{msec}(0.88 \mathrm{nA})$. Note that these time constants are similar to those for the onset of cross-desensitization of the 5-nitrowillardiine response by AMPA.

receptor until 5-nitrowillardiine dissociates. The slow relaxation of the kainate response in the presence of 5-nitrowillardiine exhibited a time course similar to the onset of cross-desensitization of responses to 5-nitrowillardiine by AMPA and was well fit by the sum of two exponentials; the time constants were 102 $\pm 27 \mathrm{msec}(43 \%)$ and $404 \pm 212 \mathrm{msec}(57 \%)(n=6)$.
Kinetic analysis of interactions between 5-substituted willardiines

Further evidence supporting activation of a common receptor by 5 -substituted willardiines is provided by agonist interaction experiments. Although willardiine, 5-fluorowillardiine, and 5 -iodowillardiine all produce responses with a rapidly but incompletely desensitizing component (e.g., Figs. $3 A ; 6 A, B$ ), coapplication of $4 \mathrm{mM}$ willardiine or $200 \mu \mathrm{M}$ 5-fluorowillardiine together with $200 \mu \mathrm{M}$ 5-iodowillardiine produced marked inhibition of the equilibrium response to 5-iodowillardiine (Fig. 6). This is similar to the cross-desensitization observed during coapplication of AMPA and 5-nitrowillardiine (Fig. 5) and occurs because $4 \mathrm{mM}$ willardiine and $200 \mu_{\mathrm{M}}$ 5-fluorowillardiine produce much stronger desensitization (91\% and $92 \%)$ than 200 $\mu \mathrm{M} 5$-iodowillardiine (64\%). Also, similar to the interaction of AMPA and 5-nitrowillardiine, preincubation with 5-iodowillardiine abolishes the large-amplitude, rapidly desensitizing response to both willardiine and 5-fluorowillardiine (Fig. 6); this suggests that a common receptor mediates the rapidly desensitizing and equilibrium components of the response to each of these agonists.

The kinetics of recovery of responses to 5-iodowillardiine following removal of willardiine or 5-fluorowillardiine varied with the structure of the agonist used to evoke cross-desensitization. For both willardiine and 5-fluorowillardiine, recovery from block followed double-exponential kinetics, but the rate of recovery was much faster for willardiine than for 5-fluorowillardiine. This difference in the kinetics of recovery from crossdesensitization reflected both a 1.3 -fold increase in the relative amplitude of the amount of recovery accounted for by the slow component in the case of 5-fluorowillardiine (Fig. 6C), as well as recovery time constants 2.1 and 4.1 times slower for 5-fluorowillardiine compared to those for willardiine.

\section{Deactivation kinetics following termination of the application of willardiine derivatives}

Responses to willardiine derivatives, as well as responses to quisqualate and AMPA, show unusually prolonged tail currents after the application of agonist is terminated (e.g., Figs. 2, 3). Such slow tail currents are pronounced following responses evoked by agonists of high potency which produce strong desensitization (5-fluorowillardiine, quisqualate, and AMPA), but are also apparent, although less obvious, following strongly desensitizing responses to agonists of lower potency such as willardiine (Fig. 2) and the ( $S$ )- and $(R)$-enantiomers of homocysteic acid (e.g., Fig. 1 of Patneau and Mayer, 1991). In the present experiments we analyzed tail current kinetics following application of willardiine and 5-fluorowillardiine (Fig. 7). Such responses, from experiments on seven cells (15 observations), were well fit by the sum of two exponentials, with the following time constants $\left(\tau_{f}\right.$ and $\tau_{s}$ ) and amplitudes (expressed as a percentage of the steady-state current): 5-fluorowillardiine, $\tau_{f} 36.3$ $\pm 11.5 \mathrm{msec}(48 \pm 12 \%)$ and $\tau_{s} 313 \pm 89 \mathrm{msec}(52 \pm 12 \%)$; willardiine; $\tau_{f} 37.8 \pm 9.4 \mathrm{msec}(85 \pm 8 \%)$ and $\tau_{s} 204 \pm 73 \mathrm{msec}$ $(15 \pm 8 \%)$. This analysis revealed that the prominent tail current following responses to 5 -fluorowillardiine arises because $\tau_{s}$ accounts for a much larger component of the off-response (52\%) than is the case for willardiine $(15 \%)$ and, in addition, that $\tau_{s}$ was slower for 5-fluorowillardiine than for willardiine.

This difference in the kinetics of responses to 5-fluorowillardiine versus willardiine is reminiscent of differences in the ki- 
netics of recovery of responses to 5-iodowillardiine following cross-desensitization evoked by 5 -fluorowillardiine and willardiine, suggesting that the two processes may be related. Both types of response are consistent with a scheme in which willardiine and 5-fluorowillardiine exhibit different affinities for a ligand-bound desensitized state of the AMPA/kainate receptor, and suggest a model in which this ligand-bound desensitized state is in equilibrium with a closed state of the receptor, which in turn has rapid access to the open state.

\section{Discussion}

Unusual features of the response to activation of AMPA/kainate receptors in CNS neurons include an initial response to AMPA at least twofold larger than that to kainate when both agonists are applied at maximally effective concentrations (Patneau and Mayer, 1991), and marked desensitization evoked by AMPA but not kainate (Mayer and Vyklicky, 1989; O'Dell and Christensen, 1989; Kiskin et al., 1990; Patneau and Mayer, 1990, 1991). Thus, before the onset of desensitization, kainate appears to be a partial agonist and AMPA a full agonist, while at equilibrium AMPA appears to be a partial agonist and kainate a full agonist. In the present experiments, 5-substituted willardiines appear to act as full agonists prior to the onset of desensitization, and as partial agonists at equilibrium; willardiine appears to be a partial agonist both before and after the onset of desensitization.

It has not yet been possible to determine whether there exist multiple subtypes of AMPA/kainate receptor in individual hippocampal neurons, but the balance of evidence from experiments on adult (Jonas and Sakmann, 1991) and embryonic ncurons (Patncau and Maycr, 1990) suggests that activation of a single family of receptors with nearly identical properties underlies both the rapidly desensitizing and equilibrium components of responses to AMPA and kainate. That AMPA and kainate can produce their characteristically distinct patterns of physiological response at a single molecular species of receptor is known to be true from experiments on homomeric receptors expressed from mRNAs coding for single glutamate receptor subunits (Keinånen et al., 1990). The pattern of responses to AMPA and kainate observed in CNS neurons most closely resembles that of heteromeric receptors generated by coexpression of cDNA sequences coding for the splice variants GluR A-flip and GluR B-flop (Sommer et al., 1990). Although results from in situ hybridization experiments suggest that CA1 and CA3 hippocampal neurons are likely to contain subtypes of AMPA/ kainate receptor formed from assembly of different combinations of subunits, the descnsitization kinetics of AMPA/kainate receptors in membrane patches from $\mathrm{CA} 1$ and $\mathrm{CA} 3$ neurons are very similar, suggesting that in these neurons functional differences between receptor subtypes may be limited (Jonas and Sakmann, 1991). In the present experiments, when several agonists were tested on the same cell, the pattern of desensitization produced by different willardiine derivatives remained highly consistent from cell to cell, suggesting either expression of a single receptor subtype or expression of multiple receptors at a constant relative density. The balance of our experimental evidence suggests that the marked differences in desensitization produced by novel willardiine derivatives are unlikely to result from differential activation of distinct receptor subtypes, although this cannot be absolutely excluded. Instead, we suggest that the large differences in the degree of desensitization produced by willardiine and its 5 -substituted derivatives must re-
A

B
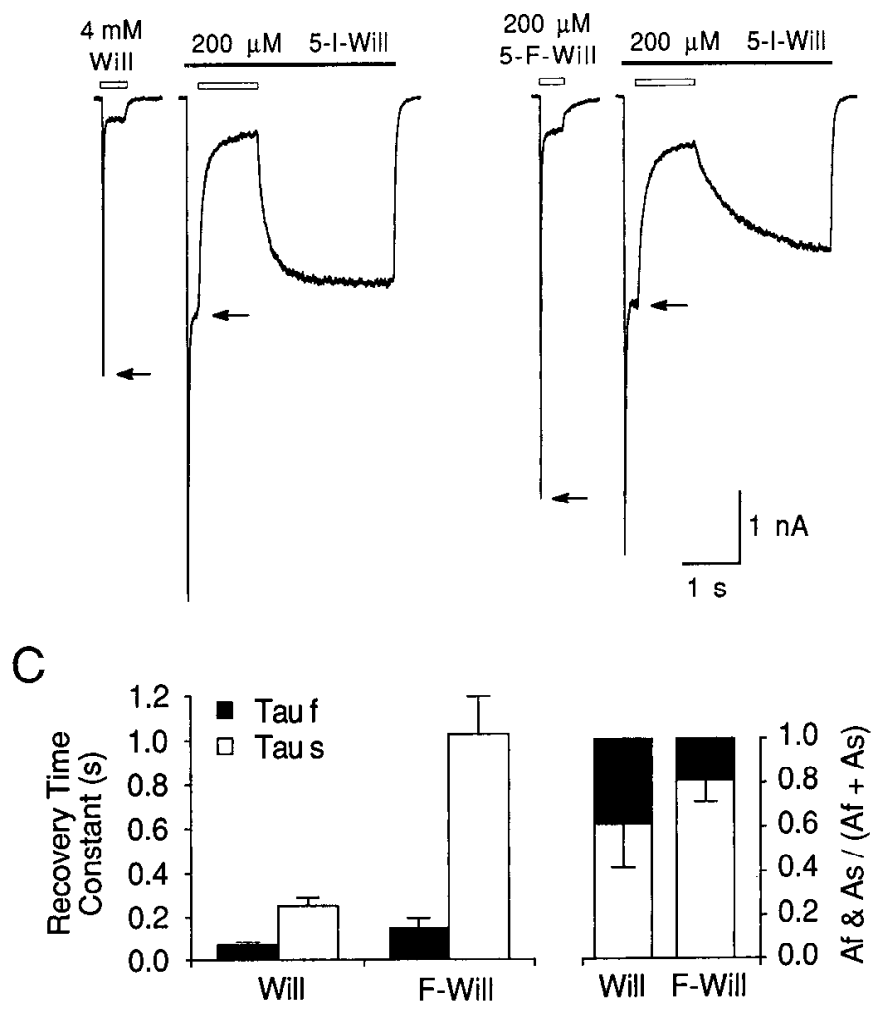

Figure 6. Interactions between 5-iodowillardiine and either willardiine or 5-fluorowillardiine. $A$, Comparison of the amplitude of responses to $4 \mathrm{~mm}$ willardiine applied alone and in the presence of $200 \mu \mathrm{M} 5$-iodowillardiine, as indicated by bars above each record. Arrows indicate the peak response to willardiine; note block of the peak response in the presence of 5-iodowillardiine. The onset of desensitization of the control response to willardiine was rapid and best fit by the sum of two exponentials $\left(\tau_{f}: 9.8 \mathrm{msec}, 93 \% ; \tau_{s}: 48 \mathrm{msec}, 7 \%\right)$. $B$, A similar experiment with $200 \mu \mathrm{M} 5$-fluorowillardiine recorded from the same cell. The onset of desensitization of the control response to 5 -fluorowillardiine was also rapid $\left(\tau_{f}: 11 \mathrm{msec}, 93 \% ; \tau_{s}: 66 \mathrm{msec}, 7 \%\right)$. Note the larger amplitude of the peak response to 5 -fluorowillardiine relative to willardiine. The rates of recovery from desensitization of the equilibrium response to 5-iodowillardiine following removal of willardiine and 5-fluorowillardiine were fit with the sum of two exponentials: $I_{\text {total }}=A_{f} \exp ^{-t / \tau_{f}}+A_{s} \exp ^{-t / \tau_{s}}+A_{0}$, where $\tau_{f}$ and $\tau_{s}$ are the fast and slow time constants; $A_{f}$ and $A_{s}$, their relative amplitudes; and $A_{0}$, the amplitude of the steady-statc responsc. Recovery of the response to 5-iodowillardiine was much faster following desensitization evoked by willardiine $\left(A ; \tau_{f}, 81 \mathrm{msec} ; \mathrm{A}_{f}, 50 \% ; \tau_{s}, 293\right.$ msec; $\left.A_{s}, 50 \%\right)$ than by 5 -fluorowillardiine $\left(B ; \tau_{f}, 110 \mathrm{msec} ; A_{f}, 7 \% ; \tau_{s}\right.$, $\left.860 \mathrm{msec} ; A_{s}, 93 \%\right) . C$, Experiments were performed as in $A$ and $B$ on six cells; values for $\tau_{f}$ and $\tau_{s}(l e f t)$ and $A_{f}$ and $A_{s}(r i g h t)$ show mean \pm SD.

flect an influence of agonist structure on desensitization at AMPA/kainate receptors.

\section{Comparison with previous work}

Our results provide a possible explanation for the original observations of Agrawal and Evans (1986) concerning depolarization of rat sensory neuron axons by 5-bromowillardiine, but not willardiine. In hippocampal neurons the 6.8 -fold difference in the relative efficacy of willardiine and 5-bromowillardiine at equilibrium results from differences in the degree of desensitization evoked by these agonists. Similar factors may have been involved in the experiments of Agrawal and Evans (1986) because glutamate receptors on sensory neuron cell bodies show 


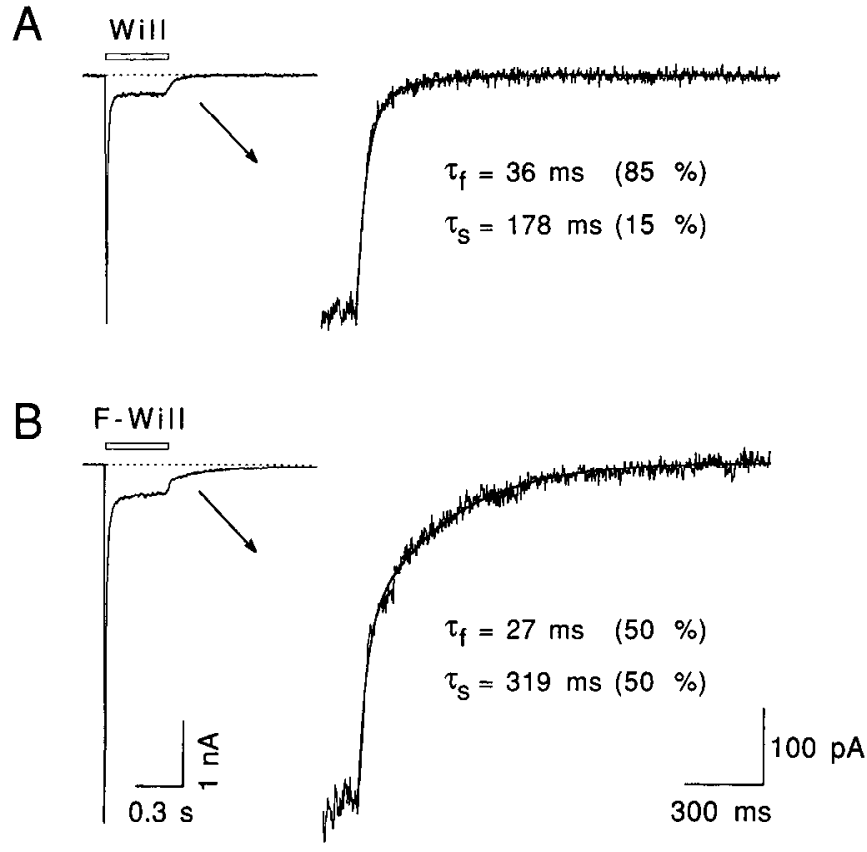

Figure 7. Deactivation kinetics of responses to willardiine and 5-fluorowillardiine. $A$ and $B$ show responses to willardiine $(4 \mathrm{~mm})$ and 5-fluorowillardiine $(200 \mu \mathrm{M})$ applied for $400 \mathrm{msec}$ as indicated by open bars above the traces (left); traces on the right are on an expanded scale and show the tail current recorded following termination of the application of agonist. $A$, The tail current following termination of the application of willardiine decayed with double-exponential kinetics; the slow $\left(\tau_{s}\right)$ time constant was $178 \mathrm{msec}$ but accounted for only $15 \%$ of the tail current amplitude. $B$, Decay of the tail current following termination of the application of the higher-affinity agonist 5-fluorowillardiine was slower, and $\tau_{s}(319 \mathrm{msec})$ accounted for a larger proportion of the tail current (50\%). Responses in $A$ and $B$ are from the same cell illustrated in Figure 6.

complete and rapid desensitization in response to AMPA, glutamate, and quisqualate and incomplete, slow but substantial desensitization in response to kainate and domoate (Huettner, 1990). Thus, on sensory neurons willardiine would be expected to produce rapid, complete desensitization, and 5-bromowillardiine slow, incomplete desensitization. An additional reason for the apparent lack of response of sensory neuron axons to willardiine is that, as discussed below, willardiine appears to be less efficacious than other AMPA/kainate receptor agonists. Experiments to test these hypotheses are in progress.

Results obtained in experiments on AMPA/kainate receptors expressed in Xenopus oocytes (Sugiyama ct al., 1989), in which $(R, S)$-willardiine $(1 \mathrm{~mm})$ but not $(R, S)$-5-bromowillardiine $(1$ mM) produced block of responses to $100 \mu \mathrm{M}$ kainate, appear to conflict with the results of our experiments on hippocampal neurons. However, the oocyte response to $100 \mu \mathrm{M}$ kainate will be submaximal (e.g., Verdoorn and Dingledine, 1988) while a concentration of $1 \mathrm{mM}(R, S)$-5-bromowillardiine should be saturating for activation of equilibrium responses at AMPA/kainate receptors. Although the occurrence of small differences in the relative potency of kainate in oocytes and hippocampal neurons complicates precise comparisons, we calculate from the data summarized in Table 1, using an $\mathrm{EC}_{50}$ of $143 \mu \mathrm{M}$ for kainate (Patneau and Mayer, 1990), that the equilibrium response to 1 mM $(R, S)$-5-bromowillardiine in hippocampal neurons would be 1.53 times larger than the response to $100 \mu \mathrm{M}$ kainate; thus, in oocytes, at the above concentrations, coapplication of 5-bro- mowillardiine would not be expected to block the response to kainate. When applied together there will be competition between kainate and 5-bromowillardiine such that their effects will not be additive; it is probable that such an effect underlies the small increase in the oocyte response observed by Sugiyama et al. (1989) when switching from kainate applied alone to kainate plus 5-bromowillardiine.

\section{Willardiines are potent agonists}

The 5-substituted derivatives of willardiine represent a new class of AMPA/kainate receptor agonist of unusually high potency. The $(S)$-isomers of the 5-fluoro, 5-nitro, 5-chloro, and 5-bromo derivatives are 2-13 times more potent at equilibrium than $(S)$ glutamate but, like $(S)$-glutamate, produce rapidly desensitizing responses with peak amplitudes at least twice as large as the maximum response to a saturating dose of kainate (e.g., Patneau and Mayer, 1991). The lowest-potency derivative tested, $(S)-5$ iodowillardiine, which at a maximally effective dose produces an equilibrium response $90 \%$ as large as that evoked by a saturating dose of kainate, is equipotent with glutamate and 7.4 times more potent than kainate. $(S)$-5-fluorowillardiine $\left(\mathrm{EC}_{50}\right.$, $1.5 \mu \mathrm{M})$ is of similar potency to $(S)$-quisqualate $\left(\mathrm{EC}_{50}, 0.9 \mu \mathrm{M}\right.$; Patneau and Mayer, 1990), the most potent AMPA-like ligand identified to date in physiological experiments.

Equilibrium potency measurements are valuable because they allow comparison with data obtained from other preparations using slow applications of agonists, but do not give an accurate estimate of agonist potency before the onset of desensitization. Our perfusion apparatus, despite its relatively fast exchange time constant, produces distortion of the dose-response curve for the peak response to low doses of agonists that produce rapid desensitization. Despite this, it is clear that willardiine derivatives, similar to other agonists that produce rapidly desensitizing responses, exhibit substantial differences in affinity for the resting and desensitized states of AMPA/kainate receptors, such that equilibrium $\mathrm{EC}_{50}$ measurements lie between the high-affinity $K_{d}$ for agonist binding to the desensitized state and the low-affinity $K_{d}$ for agonist binding to the resting state.

\section{Kinetic simulations}

To gain insight into the mechanism of action of willardiine derivatives, we performed numerical simulations using a fivestate model, as shown below. Although there is already good evidence for the need for more complex models, involving multiple desensitized states and with more than one agonist binding site per receptor-channel complex (e.g., Trussell and Fischbach, 1989; Patneau and Mayer, 1991), a five-state model can still give useful insight into the action of willardiines:

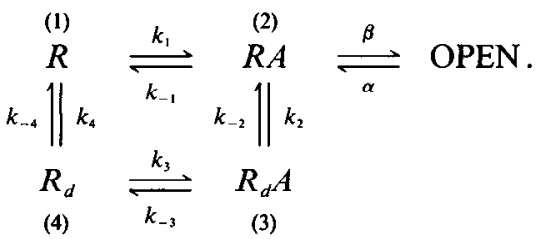

$A$ represents agonist, and $R$ and $R_{d}$ represent the resting and desensitized states of an AMPA/kainate receptor, with (states 2 and 3) or without (states 1 and 4) agonist bound. The model used incorporates the following assumptions: The opening $(\beta)$ and closing $(\alpha)$ rate constants were set at $1000 \mathrm{sec}^{-1}$ and 300 $\mathrm{sec}^{-1}$, respectively, to give a maximum open probability of 0.77 
(e.g., Huettner, 1990), and a brief mean open time (e.g., Tang et al., 1989); $k_{4}$ and $k_{-4}$, the rate constants for entry into and recovery from the desensitized state for receptors that have not bound agonist, were assigned values of $0.01 \mathrm{sec}^{-1}$ (forward) and $1 \mathrm{sec}^{-1}$ (backward), to give only $1 \%$ desensitization at rest and a moderately slow transition from the unliganded desensitized state to the resting state; $k_{2}$ and $k_{-2}$, the rate constants for entry into and recovery from the desensitized state for receptors that have bound agonist, were initially assigned values of $500 \mathrm{sec}^{-1}$ (forward) and $10 \mathrm{sec}^{-1}$ (backward) to give rapid and substantial entry into the agonist-bound desensitized state, consistent with the rapid and strong desensitization observed experimentally (e.g., Figs. 3, 6); $k_{1}$ was set at $10^{7} \mathrm{M}^{-1} \mathrm{sec}^{-1}$ to give fast binding of agonist to the resting receptor, and the dissociation rate constant $k_{-1}$ was varied to set the agonist affinity; $k_{3}$, the forward rate constant for binding of agonist to the desensitized state of the receptor, was also set at $10^{7} \mathrm{M}^{-1} \mathrm{Sec}^{-1}$; the value for $k_{-3}$, the rate constant for dissociation of agonist from the desensitized state, is constrained by the law of microscopic reversibility and determined by the other rate constants. To allow differences in the peak amplitude of responses to saturating doses of AMPA and kainate, the open state activated by AMPA was assigned a conductance of $10 \mathrm{pS}$, and the open state activated by kainate, a conductance of $3 \mathrm{pS}$. Such agonist-dependent gating has precedent from the experiments of Jahr and Stevens (1987) and Cull-Candy and Usowicz (1987), though this point remains controversial. Alternatively, setting $\beta$, the opening rate constant, to a lower value for kainate than for AMPA would also produce the experimentally observed difference in response amplitude.

With $k_{-1}$ set at $500 \mathrm{sec}^{-1}\left(K_{d}=50 \mu \mathrm{M}\right.$ for binding of agonist to the resting state) and $k_{-3}$ equal to $0.1 \mathrm{sec}^{-1}\left(K_{d}-10 \mathrm{~nm}\right.$ for binding of agonist to the desensitized state), the model produces a response similar to that evoked by $(S)$-5-fluorowillardiine (Fig. $8 A$, Model 1): The equilibrium $\mathrm{EC}_{50}$ is $0.91 \mu \mathrm{M}$; desensitization with $200 \mu \mathrm{M}$ agonist proceeds rapidly, with a time constant of $10.8 \mathrm{msec}$, and reaches $87 \%$ at equilibrium. After the application of agonist is terminated there is a prolonged tail current, which is well fit by the sum of two exponentials (see Fig. 7) and decays with time constants of $7.3 \mathrm{msec}\left(\tau_{j}\right.$; relative amplitude, $48 \%$ ) and $200 \mathrm{msec}\left(\tau_{s} ;\right.$ relative amplitude, $\left.52 \%\right)$.

The maximum peak response to a saturating concentration of willardiine was of consistently lower amplitude than the response to the other agonists tested (Fig. 3). In principle, this can occur via at least three mechanisms: a lower open probability once willardiine has bound, due to a change in the ratio $[(\beta / \alpha) /$ $(1+\beta / \alpha)$, a decrease in ratio $k_{1}$ relative to $k_{2}$, or experimentally slow application of agonist with respect to the kinetics of activation and desensitization. The latter problem is potentially of concern for agonists of low potency, but we do not believe such an artifact underlies the partial agonist action of $(S)$-willardiine because the peak response to a saturating dose of $S$-sulfo-( $S)$ cysteine $(10 \mathrm{mM})$, which is of comparable equilibrium potency to $(S)$-willardiine, was on average $1.99 \pm 0.23$ times larger than the peak response to $10 \mathrm{mM}(S)$-willardiine. The peak response to $25 \mathrm{~mm}(S)$-homocysteate, which at equilibrium is 10.6 times less potent than $(S)$-willardiine, was also larger $(1.83 \pm 0.11$ times) than the response to $10 \mathrm{~mm}(S)$-willardiine. In view of this, we modeled the response to willardiine by lowering $\beta$ to $600 \mathrm{sec}^{-1}$, to produce a less efficacious agonist, and set $k_{-1}$ at $20,000 \mathrm{sec}^{-1}\left(K_{d}=2 \mathrm{mM}\right.$ for binding of agonist to the resting state) with $k_{-3}$ equal to $4 \mathrm{sec}^{-1}\left(K_{d}=0.4 \mu \mathrm{M}\right.$ for binding of agonist to the desensitized state). This produces a less potent agonist with a peak response smaller than observed in other simulations (model 2, Fig. 8) and similar to that evoked by $(S)$-willardiine when applied to hippocampal neurons (compare Fig. 7): The equilibrium $\mathrm{EC}_{50}$ was $36 \mu \mathrm{M}$; desensitization with $4 \mathrm{mM}$ agonist proceeds rapidly, with a time constant of $8.8 \mathrm{msec}$, reaching $88 \%$ at equilibrium. After the application of agonist is terminated the tail current decays rapidly, with time constants of 3.5 msec $\left(\tau_{f} ;\right.$ relative amplitude, $\left.97 \%\right)$ and $73 \mathrm{msec}\left(\tau_{s}\right.$; relative amplitude, $3 \%$ ).

Agonist responses with rapid but weak desensitization, similar to those evoked by $(S)$-5-iodowillardiine, require a change in the ratio of the relative affinity of agonist for the resting and desensitized states of the AMPA/kainate receptor. With the forward rate constant for agonist binding to the desensitized state of the receptor $\left(k_{3}\right)$ fixed, this can only be achieved by increasing $k_{-3}$, the rate constant for dissociation of agonist from the desensitized state of the receptor; for microscopic reversibility to be satisfied, $k_{-2}$ must also increase. To simulate responses to 5-iodowillardiine (Fig. $8 A$, Model 3 ), agonist affinity for the resting state was lowered four-fold, to $200 \mu \mathrm{M}$, by setting $k_{-1}$ at $2000 \mathrm{sec}^{-1} ; k_{-3}$ was set at $2 \mathrm{sec}^{-1}$, and the rate of recovery from desensitization increased five-fold by setting $k_{-2}$ to $50 \mathrm{sec}^{-1}$. This resulted in a 20 -fold reduction in the affinity of agonist for the desensitized state of the receptor $\left(K_{d}=200 \mathrm{nM}\right)$. The equilibrium $\mathrm{EC}_{\text {s0 }}$ for model 3 is $35 \mu \mathrm{M}$; desensitization with $2 \mathrm{mM}$ agonist proceeds rapidly, with a time constant of $8.1 \mathrm{msec}$, but reaches only $53 \%$. There is a moderately slow tail current after the application of agonist was terminated, which decays with time constants of $4.7 \mathrm{msec}\left(\tau_{f}\right.$; relative amplitude, $75 \%$ ) and $24 \mathrm{msec}$ $\left(\tau_{s} ;\right.$ relative amplitude, $\left.25 \%\right)$.

To test further the validity of the above models, we ran simulations in which the interaction between 5-nitrowillardiine (Fig. $8 A$, Model 4) and kainate was simulated with protocols similar to those used experimentally (e.g., Fig. $5 B$ ). The response to 5-nitrowillardiine was modeled with $k_{-1}$ at $2500 \mathrm{sec}^{-1}, k_{-2}$ set at $10 \mathrm{sec}^{-1}$, and $k_{-3}$ set at $0.5 \mathrm{sec}^{-1}$. The equilibrium $\mathrm{EC}_{50}$ for model 4 is $4.5 \mu \mathrm{M}$, and desensitization with $1 \mathrm{~mm}$ agonist proceeds rapidly, reaching $87 \%$ at equilibrium. The response to kainate was modeled with an open state of $3 \mathrm{pS}$ conductance and setting $k_{-1}$ at $1500 \mathrm{sec}^{-1}\left(K_{d}=150 \mu \mathrm{M}\right.$ for binding of agonist to the resting state), $k_{2}$ at $10 \mathrm{sec}^{-1}, k_{-2}$ at $1000 \mathrm{sec}^{-1}$, and $k_{-3}$ at $1500 \mathrm{sec}^{-1}\left(K_{d}=150 \mu \mathrm{M}\right.$ for binding of agonist to the desensitized state). With this combination of rate constants, simulated responses to kainate are reduced in amplitude and show slow activation in the presence of 5-nitrowillardiine (Fig. $8 B$ ), similar to experimental observations (Fig. $5 B$ ). The above models also reproduce the cross-desensitization that occurs between 5-fluorowillardiine and 5-iodowillardiine (compare Figs. 6B, 8C).

\section{Both activation and desensitization are influenced by simple changes in molecular structure}

Our experimental data, together with the simulations shown in Figure 8, suggest that introduction of an electron-withdrawing group at ring position 5 in the willardiine molecule increases agonist affinity for both the resting and desensitized states of the AMPA/kainate receptor(s) present on hippocampal neurons. Not only are all the derivatives more potent than willardiine itself, but the potency sequence (equilibrium $\mathrm{EC}_{50}$ values: $\mathrm{F}=1.5$, $\mathrm{Cl}=7.3, \mathrm{Br}=8.8$, and $\mathrm{I}=19.2 \mu \mathrm{M}$, respectively) follows the halogen electronegativity sequence $\mathrm{F}>\mathrm{Cl}>\mathrm{Br}>\mathrm{I}$. Based on an analysis of the effect of electron-withdrawing groups on the $\mathrm{p} K_{a}$ of some derivatives of uracil (Wempen and Fox, 1964) and 
A

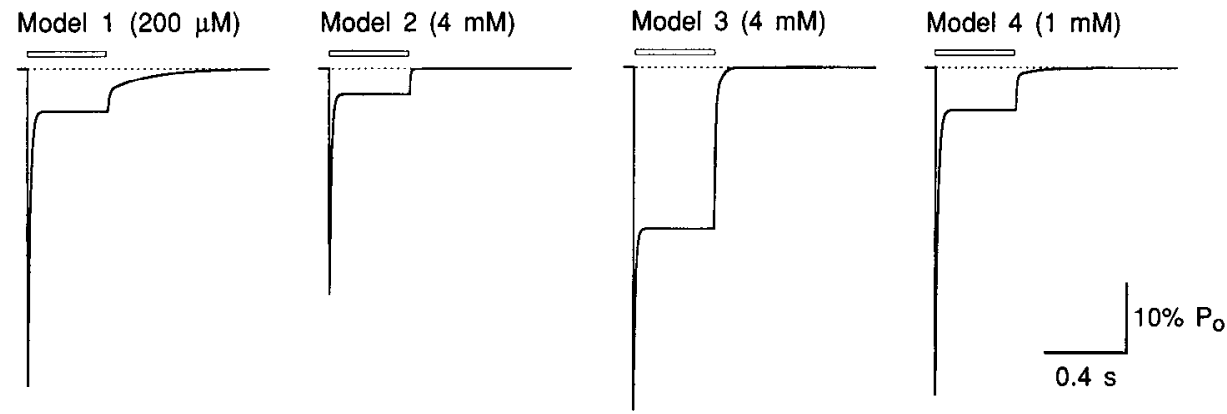

B

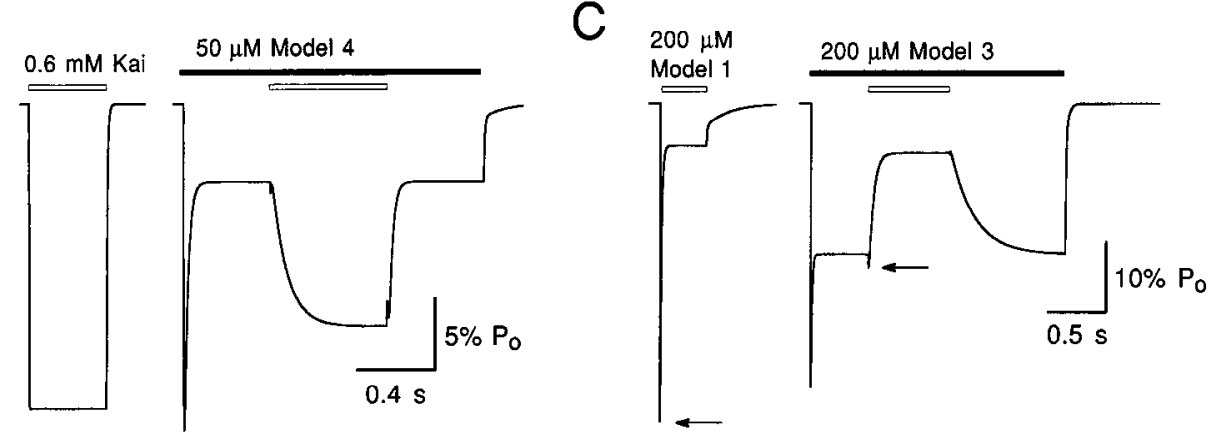

Figure 8. Simulation of agonist responses to willardiines. $A$, Parameters for a five-state model were adjusted as described in the Discussion to produce responses with 5-fluorowillardiine-like (Model 1), willardiine-like (Model 2), 5-iodowillardiine-like (Model 3), or 5-nitrowillardiine-like (Model 4) characteristics. Each simulation shows the response to agonist applied during the time indicated by open bars above the traces, at concentrations approximately 100-200 times the equilibrium $\mathrm{EC}_{50}$ (determined by measurement of the simulated response to a series of six to eight agonist concentrations, as shown in Fig. 2). Note the slow tail current following termination of the application of agonist in Model 1 . $B$ shows a simulation of the interaction between kainate and 5-nitrowillardiine (Model 4); the peak response to the application of $50 \mu \mathrm{M}$ agonist simulated by Model 4 is submaximal. $C$ shows a simulation of cross-desensitization between 5-iodowillardiine (Model 3) and 5-fluorowillardiine (Model I); arrows indicate the peak response to 5-fluorowillardiine applied alone and in the presence of 5-iodowillardiine. Simulations were performed as described in Benveniste et al. (1990) using an improved version of the FASTFLo program written by Dr. J. Clements (Vollum Institute) and assumed instantaneous solution changes. The amplitude scale is given in terms of open probability $\left(P_{o}\right)$ and, for the response to kainate, should be multiplied by $10 / 3$.

willardiine (Lidak et al., 1972), a probable explanation for this correlation is a preference of AMPA/kainate receptors for willardiine derivatives with charged as opposed to uncharged uracil rings (Table 2). This is because substitution of electron-withdrawing groups at the 5-position of the willardiine molecule would be expected to increase substantially the concentration of the negatively charged species of agonist at physiological $\mathrm{pH}$, as shown on the right. At present there is no evidence that any of the canonical forms of willardiine illustrated below occur

Table 2. $\mathrm{p} K_{a}$ values for 5-substituted uracils and willardiines

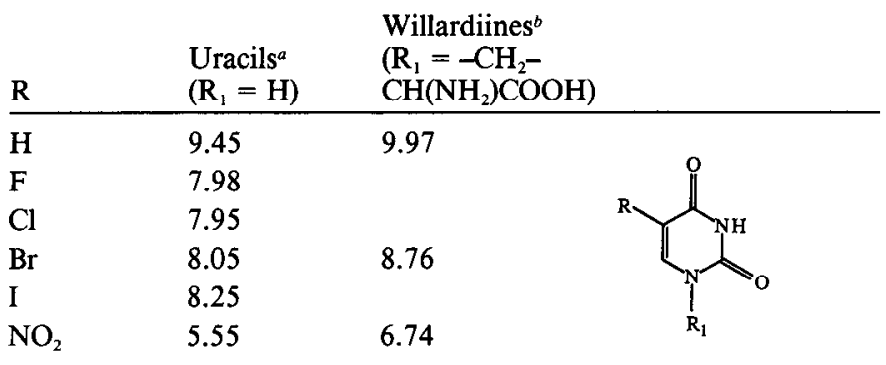

Wempen and Fox (1964).

${ }^{\circ}$ Lidak et al. (1972). preferentially at physiological $\mathrm{pH}$. The negatively charged group in the uracil ring of willardiines is expected to be functionally equivalent to the $\omega$-COOH group in glutamate:

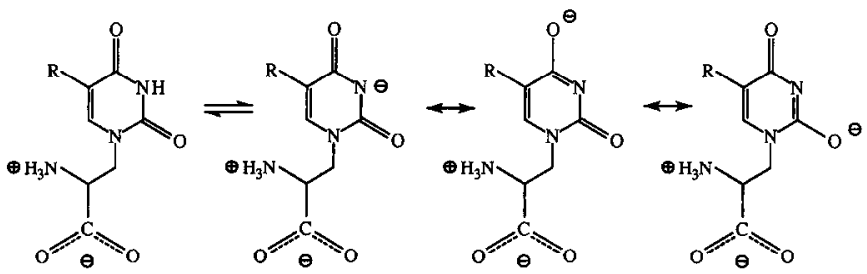

The above effect of 5-substitution does not, however, explain the rank order of the ability of the substances to cause desensitization, because willardiine (with the least acidic uracil moiety) produces more desensitization than the much more acidic 5-fluoro and, particularly, 5-nitro derivatives. We suggest that size of the 5-substituent plays a major role in determining the degree of desensitization evoked by these substances. One attractive explanation would be that 5 -position substituents sterically hinder the conformational change from the resting to the desensitized state of AMPA/kainate receptors and as a result decrease the forward rate constant $\left(k_{2}\right)$ for entry into the desensitized state. However, although decreasing $k_{2}$ does reduce the amount of desensitization produced by these simple models, it also markedly reduces the rate of onset of desensitization, an 
effect not seen with (S)-5-iodowillardiine or any of the other agonists tested, but which may be relevant for the action of drugs that reduce desensitization (Vyklicky et al., 1991). Rather, as described above for model 3 (Fig. 8), our observations suggest that the affinity of the desensitized state of the receptor for agonist relative to that for the resting state decreases with increasing size of the 5-substituent, and that this difference is greatest for 5-iodowillardiine versus 5-fluorowillardiine. Therefore, the correlation between $\mathrm{EC}_{50}$ and amount of desensitization graphed in Figure $4 B$ most likely reflects the effect of both electronegativity and size of the 5-substituent; thus, $\mathrm{NO}_{2}$, the most electronegative group used, produces less desensitization than the fluoro derivative, probably as a result of the larger size of the $\mathrm{NO}_{2}$ group. Hydrophobic and $\pi$-orbital interactions with the receptor are additional factors that may contribute to the action of willardiines, but the compounds synthesized to date do not provide clear information on this point.

The simple models described above only approximate the behavior of AMPA/kainate receptors. For example, although the onset of desensitization is best described as a two-exponential process (Figs. 3,6), in the simulations the onset of desensitization was well fit by a single exponential. Despite this limitation, the models provide important clues concerning possible molecular changes underlying agonist-dependent desensitization. A five-state model with different affinity for binding of agonist to resting and desensitized states provides a plausible explanation for the relative amounts of desensitization produced by the willardiine derivatives examined, for differences in the kinetics of recovery from desensitization, and for changes in deactivation kinetics following removal of agonist. Modeling also climinates from consideration changes in the forward rate constant for desensitization as an explanation for differences in amount of desensitization and suggests that future experimental efforts would profit from attempts to measure the rate constants for recovery from desensitization. A marked ( $>1000$-fold) difference in the affinity of agonists for the resting and desensitized states of AMPA/kainate receptors is suggested by such models, and raises the issue of how to determine agonist affinity accurately for different receptor states.

Further work with willardiine derivatives containing other substitutions, especially at the 6-position, may provide additional insight into the strikingly different physiological response of CNS AMPA/kainate receptors to kainic acid and its derivatives versus isoxazole derivatives typified by AMPA. The wide range in the degree of desensitization among willardiine derivatives may also prove useful in the characterization of cloned glutamate receptor subtypes and in the identification of subtypes of glutamate receptors expressed in neurons and glia from different parts of the brain. In support of this, preliminary experiments indicate that for activation and desensitization of AMPAV kainate receptors on immature rat dorsal root fibers, the potency sequence of 5-substituted willardiines is the inverse of that observed in experiments on hippocampal neurons (Blake et al., 1991).

Note added in proof. Following submission of this article we obtained additional evidence that the marked differences in desensitization produced by willardiine and its derivatives are not due to differential activation of a heterogenous receptor population. Recombinant glutamate receptors, formed when GluRA-flip and GluR-B-flop subunits (a gift from Dr. P. Seeburg) are coexpressed in the human embryonic kidney cell line 293 , respond to willardiine and its derivatives similar to native receptors on mouse hippocampal neurons (D. K. Patneau, unpublished observations).

\section{References}

Agrawal SG, Evans RH (1986) The primary afferent depolarizing action of kainate in the rat. Br J Pharmacol 87:345-355.

Benveniste M, Clements J, Vyklicky L Jr, Mayer ML (1990) A kinetic analysis of the modulation of $N$-methyl-D-aspartic acid receptors by glycine in cultured mouse hippocampal neurones. J Physiol (Lond) 428:333-357.

Blake FF, Jane DE, Watkins JC (1991) Action of willardiine analogues on immature rat dorsal roots. $\mathrm{Br} \mathrm{J}$ Pharmacol, in press.

Boulter J, Hollmann M, O'Shea-Greenfield A, Hartley M, Deneris E, Maron C, Heinemann S (1990) Molecular cloning and functional expression of glutamate receptor genes. Science 249:1033-1037.

Bowie D, Smart TG (1991) Interaction of 5-bromowillardiine with non-NMDA receptors expressed in Xenopus laevis oocytes injected with chick brain mRNA. Neurosci Lett 121:68-72.

Charpentier N, Dumuis A, Sebben J, Bockaert J, Pin JP (1990) On concanavalin A-treated neurons quisqualate clearly behaves as a partial agonist of a receptor fully activated by kainate. Eur J Pharmacol 189:241-251.

Cull-Candy SG, Usowicz MM (1987) Multiple-conductance channels activated by excitatory amino acids in cerebellar neurones. Nature 325:525-528.

Davies J, Evans RH, Jones AW, Smith DAS, Watkins JC (1982) Differential activation and blockade of excitatory amino acid receptors in the mammalian and amphibian central nervous system. Comp Biochem Physiol [C]72:21 1-224.

Evans RH, Jones AW, Watkins JC (1980) Willardiine: a potent quisqualate-like excitant. J Physiol (Lond) 308:71P-72P.

Gmelin R (1961) Isolierung von willardiin (3-(1-uracyl)-L-alanin) aus den samen von Acacia millefolia, Acacia lemmoni und Mimosa asperata. Acta Chem Scand 15:1188-1189.

Guthrie PB, Brenneman DE, Neale EA (1987) Morphological and biochemical differences expressed in separate dissociated cell cultures of dorsal and ventral halves of the mouse spinal cord. Brain Res 420: 313-323.

Huettner JE (1990) Glutamate receptor channels in rat dorsal root ganglion neurons: activation by kainate and quisqualate, and blockade of desensitization by concanavalin A. Neuron 5:255-266.

Ishida AT, Neyton J (1985) Quisqualate and L-glutamate inhibit retinal horizontal-cell responses to kainate. Proc Natl Acad Sci USA 82: $1837-1841$.

Jahr C, Stevens CF (1987) Glutamate activates multiple single channel conductances in hippocampal neurones. Nature 325:522-525.

Jonas P, Sakmann B (1991) Properties of AMPA subtype glutamate receptors in pyramidal cells of rat hippocampus. J Physiol (Lond), 438:321 p.

Keinånen K, Wisden W, Sommer B, Werner P, Herb A, Verdoorn TA, Sakmann B, Seeburg PH (1990) A family of AMPA-selective glutamate receptors. Science 249:556-560.

Kiskin NI, Krishtal OA, Tsyndrenko AY (1986) Excitatory amino acid receptors in hippocampal neurons: kainate fails to desensitize them. Neurosci Lett 63:225-230.

Kiskin NI, Krishtal OA, Tsyndrenko AY (1990) Cross-desensitization reveals pharmacological specificity of excitatory amino acid receptors in isolated hippocampal neurons. Eur J Neurosci 2:461-470.

Lambolez B, Curutchet P, Stinnakre J, Bregestovski P, Rossier J, Prado de Carvalho $L$ (1991) Electrophysiological and pharmacological properties of GluR1, a subunit of a glutamate receptor-channel expressed in Xenopus oocytes. Neurosci Lett 123:69-72.

Lidak MY, Dipan IV, Paegle RA, Stradyn YP (1972) Protolysis of some $\alpha$-amino- $\beta$-(1-pyrimidyl)proprionic acids and their analogs (trans from Russian). Chem Heter Comp 5:644-648.

Mayer ML, Vyklicky L Jr (1989) Concanavalin A selectively reduces desensitization of mammalian neuronal quisqualate receptors. Proc Natl Acad Sci USA 86:1411-1415.

Mayer ML, Vyklicky L Jr, Westbrook GL (1989) Modulation of excitatory amino acid receptors by group IIB metal cations in cultured mouse hippocampal neurones. J Physiol (Lond) 415:329-350.

Nakanishi N, Shneider NA, Axel R (1990) A family of glutamate 
receptor genes: evidence for the formation of heteromultimeric receptors with distinct channel properties. Neuron 5:569-581.

O'Brien RJ, Fischbach GD (1986) Characterization of excitatory amino acid receptors expressed by embryonic chick motoneurons in vitro. J Neurosci 6:3275-3283.

O'Dell TJ, Christensen BN (1989) A voltage-clamp study of isolated stingray horizontal cell non-NMDA excitatory amino acid receptors. J Neurophysiol 61:162-172.

Patneau DK, Mayer ML (1990) Structure-activity relationships for amino acid transmitter candidates acting at $N$-methyl-D-aspartate and quisqualate receptors. J Neurosci 10:2385-2399.

Patneau DK, Mayer ML (1991) Kinetic analysis of interactions between kainate and AMPA: evidence for activation of a single receptor in mouse hippocampal neurons. Neuron 6:785-798.

Patneau DK, Mayer ML, Jane DE, Watkins JC (1991) Novel willardiine derivatives exhibit varying degrees of desensitization at AMPA kainate receptors. Soc Neurosci Abstr 17:1166.

Perouansky M, Grantyn R (1989) Separation of quisqualate- and kainate-selective gluatamate receptors in cultured neurons from the rat superior colliculus. $J$ Neurosci 9:70-80.

Sommer B, Keinånen K, Verdoorn TA, Wisden W, Burnashev N, Herb A, Kohler M, Takagi T, Sakmann B, Seeburg PH (1990) Flip and Flop: a cell-specific functional switch in glutamate-operated channels of the CNS. Science 249:1580-1585.

Sugiyama H, Watanabe M, Taji H, Yamamoto Y, Ito I (1989) Phar- macological properties of quisqualate- and kainate-preferring glutamate receptors induced in Xenopus oocytes by rat and chick brain mRNA. Neurosci Res 7:164-167.

Tang CM, Dichter M, Morad M (1989) Quisqualate activates a rapidly inactivating high conductance ion channel in hippocampal neurons. Science 243:1474-1477.

Trussell LO, Fischbach GD (1989) Glutamate receptor desensitization and its role in synaptic transmission. Neuron 3:209-218.

Verdoorn TA, Dingledine R (1988) Excitatory amino acid receptors expressed in Xenopus oocytes: agonist pharmacology. Mol Pharmacol 34:298-307.

Vyklicky L Jr, Benveniste M, Mayer ML (1990) Modulation of $N$-methyl-D-aspartic acid receptor desensitization by glycine in cultured mouse hippocampal neurones. J Physiol (Lond) 428:313-331.

Vyklicky L Jr, Patneau DK, Mayer ML (1991) Modulation of excitatory synaptic transmission by drugs which reduce desensitization at AMPA/kainate receptors. Neuron 7:971-984.

Wempen I, Fox JJ (1964) Spectrophotometric studies of nucleic acid derivatives and related compounds. VI. On the structure of certain 5- and 6-halogenouracils and -cytosines. J Am Chem Soc 86:2474 2477.

Zorumski CF, Thio LL, Clifford DB (1991) Effects of bromowillardiine and willardiine on non- $N$-methyl-D-aspartate receptors in postnatal rat hippocampal neurons. Mol Pharmacol 40:45-51. 